\title{
COMPARATIVE STUDY BETWEEN INFERIOR OBLIQUE RECESSION AND INFERIOR OBLIQUE RETRO-EQUATORIAL SCLERAL FIXATION (MYOPEXY) IN MANAGEMENT OF PRIMARY INFERIOR OBLIQUE OVER ACTION
}

\author{
By \\ Mahmoud Mohamed Ismail, Mohamed Mahmoud Whdan, Heba \\ Metwally Ali and Ahmed Samir Abbas \\ Department of Ophthalmology, Al-Azhar Faculty of Medicine,Cairo, Egypt \\ Corresponding Author: Ahmed Samir Abbas \\ E-mail: ahmed.Samir.Elfikky@gmail.com, Mobile: 01007602243
}

\begin{abstract}
Background: Weakening procedures on the inferior oblique muscle are numerous and include myectomy, graded recession- anteriorization, anterior transposition, anterior and nasal transposition, myotomy, marginal myotomy, nasal myotomy, disinsertion, and denervation and extirpation. Recently, New surgical Intervention for weakening of the inferior oblique muscle is inferior oblique retro-equatorial scleral fixation ( Myopexy).

Objective: The aim of the study was to compare between recession of inferior oblique muscle(IO) and retroequatorial scleral fixation (myopexy) of inferior oblique muscle in management of primary inferior oblique over action.(IOOA)

Patients and Methods: Thirty patients (60 eyes) presented by horizontal strabismus and primary inferior oblique over action, met the inclusion criteria, and were divided into two equal groups: Group A treated by recession of the inferior oblique muscle. And Group B treated by retro-equatorial scleral fixation (myopexy) of the inferior oblique muscle.

Results: Both IO graded recession and IO myopexy were equally effective in correcting the degree of IOOA (elevation in adduction), correcting associated pattern, with no statistical significant difference and both were equally effective in correcting the degree of objective fundus extorsion with no statistical significant difference.

Conclusion: Our findings suggested that both surgical groups had positive outcomes, with good response and effect which was stable all over follow up visits uptill 6 months.
\end{abstract}

Keywords: Inferior Oblique Muscle, Graded Recession, Myopexy, V pattern, Torsion.

\section{INTRODUCTION}

The anatomy of the inferior oblique muscle is somewhat atypical compared to the other extraocular muscles, which is important for understanding the effects of the various surgical procedures on eye position and ocular motility. It is the only extraocular muscle that does not originate from the apex of the orbit and the only extraocular muscle that does not have a tendinous portion distally. It originates at the periosteum of the maxillary bone near the lacrimal fossa and inserts into the posterior globe near the inferior border of the lateral rectus, passing under the 
inferior rectus. With the eye in the primary position, the inferior oblique makes a $51^{\circ}$ angle with the visual axis and acts an excycloductor. The secondary and tertiary actions are elevation and abduction, respectively (Stager et al., 2015).

Inferior oblique over action (IOOA) is characterized by over-elevation of the eye in adduction. Primary IOOA has been reported in association with up to twothirds of infantile strabismus (esotropia and exotropia). It has also been considered the main cause of V-pattern and may be associated with dissociated vertical deviation (DVD). Secondary IOOA is observed after superior oblique muscle paresis or paralysis (Rajavi et al., 2017).

Surgery to weaken the inferior oblique muscle is indicated when the IO muscle over action is interfering with fusion or causing an abnormal head posture, asthenopia, diplopia, subjective extorsion and cosmetic problem as in cases of superior oblique palsy, primary inferior oblique over action, V-pattern horizontal strabismus with inferior oblique over action, and dissociated vertical deviation associated with inferior oblique over action (Wright, 2012).

Weakening procedures on the inferior oblique muscle are numerous and include myectomy, graded recessionanteriorization, anterior transposition, anterior and nasal transposition, myotomy, marginal myotomy, nasal myotomy, disinsertion, and denervation and extirpation (Chang et al., 2017).

New surgical intervention for weakening of the inferior oblique muscle is inferior oblique retro-equatorial scleral fixation (Myopexy) (Tomarchio et al., 2015).

The aim of the study was to compare recession of inferior oblique muscle and retroequatorial scleral fixation (myopexy) of inferior oblique muscle in management of primary inferior oblique over action.

\section{PATIENTS AND METHODS}

This was a prospective comparative non randomized interventional study which was conducted on 60 eyes. On the basis of simple random sampling these patients were divided into two equal groups, Group A was treated by recession of the inferior oblique muscle, and Group $B$ treated by retro-equatorial scleral fixation (myopexy) of the inferior oblique muscle. The study was investigated at ALHuessin University Hospital, AL- Azhr university, and Memorial Institue for Ophthalmic Research, The General Organization for Teaching Hospitals and Institutes. Informed written consent was obtained from every participant or their legal guardians after nature of the study and the possible complications were explained.

\section{Inclusion criteria:}

- Cases with primary inferior oblique over action which may be associated with horizontal strabismus (esodeviationexodeviation).

\section{Exclusion criteria:}

- Secondary inferior oblique over action.

- Inferior oblique over action with dissociated vertical deviation (DVD).

- Recurrent or residual inferior oblique over action. 


\section{COMPARATIVE STUDY BETWEEN INFERIOR OBLIQUE RECESSION... 535}

\section{Preoperative evaluation:}

\section{A- History taking:}

-Onset of the problem: ask about old photos if possible.

\section{B- Clinical examination:}

1. Assessment of anomalous head posture.

2. Assessment of facial asymmetry.

3. Assessment of amblyopia and visual acuity whenever possible.

4. Motor evaluation :

a. Assessment of any horizontal deviation if present and measurement of alignment with prism cover test or krimsky with the proper refractive correction was worn in upwards gaze, primary position and downwards gaze.

b. Assessment of ocular motility (versions) in the 9 diagnostic position of gazes, abnormal versions was noted on a scale of +1 to +4 for over-action and -1 to 4 for under action.

5. Assessment of any associated alphabetic patterns with prism cover test or krimsky with the Proper refractive correction was worn in upwards gaze, primary position and downwards gaze.
6. Sensory evaluation:Diplopia test/s: Bagolini striated lens, double Maddox rod test whenever possible.

7. Cycloplegic refraction.

8. Anterior segment examination using portable slit lamp when needed.

9. Dilated fundus examination: to detect fundus torsion; we used Guyton grading system to quantify the amount of objective torsion observed during indirect ophthalmoscopy.

\section{Post-operative follows up:}

Patients were followed up at the second day, first weak, first month, three months and six months after surgery.

\section{Statistical analysis:}

Data were analyzed using Statistical package for Social Science (SPSS) version 15.0. Quantitative data were expressed as median and inter-quartile range (IQR). Qualitative data were expressed as frequency and percentage.

Mann-Whitney $\mathbf{U}$ test was used when comparing between two medians (for abnormal distributed data), and Chisquare test was used when comparing between frequencies.

P-value $<0.05$ was considered significant. 


\section{RESULTS}

There was no statistical significant difference between group A and group B as regard age and sex (Table 1).

Table (1): Comparison between group $A$ and group $B$ as regard age and sex

\begin{tabular}{|l|c|c|c|c|c|c|}
\hline \multirow{2}{*}{ Parameters } & Groups & \multicolumn{2}{c|}{$\begin{array}{c}\text { Group A } \\
(\mathbf{N = 3 0})\end{array}$} & \multicolumn{2}{c|}{$\begin{array}{c}\text { Group B } \\
(\mathbf{N = 3 0})\end{array}$} & $\begin{array}{c}\text { P- } \\
\text { value }\end{array}$ \\
\hline \multirow{2}{*}{ Age (years) } & Median & \multicolumn{2}{|c|}{6} & \multicolumn{2}{|c|}{9} & \multirow{2}{*}{$\mathbf{0 . 0 5}$} \\
\cline { 2 - 6 } & IQR & \multicolumn{2}{|c|}{$5-9$} & \multicolumn{2}{|c|}{$5-12$} & \\
\hline \multirow{2}{*}{ Sex } & Male & 4 & $13.3 \%$ & 10 & $33.3 \%$ & \multirow{2}{*}{$\mathbf{0 . 0 5}$} \\
\cline { 2 - 6 } & Female & 26 & $86.7 \%$ & 20 & $66.7 \%$ & \\
\hline
\end{tabular}

MW: Mann-Whitney U test

Statistically significant difference occured between group A and group B as regard pre-operative elevation evaluation. No statistical significant difference between group A and group B as regard elevation evaluation at 1 week, 1 month, 3 months and 6 months (Table 2).

Table (2): Comparison between group $A$ and group $B$ as regard elevation in adduction (IOOA grade) evaluation

\begin{tabular}{|c|c|c|c|c|c|c|}
\hline \multicolumn{2}{|c|}{$\begin{array}{ll}\text { Elevation } & \text { Groups }\end{array}$} & \multicolumn{2}{|c|}{$\begin{array}{c}\text { Group A } \\
(\mathbf{N}=\mathbf{3 0})\end{array}$} & \multicolumn{2}{|c|}{$\begin{array}{l}\text { Group B } \\
(\mathbf{N}=\mathbf{3 0})\end{array}$} & P-value \\
\hline \multirow{2}{*}{$\begin{array}{c}\text { Pre- } \\
\text { operative }\end{array}$} & $\begin{array}{c}\text { Elevation } \\
\text { grade } 1\end{array}$ & 4 & $13.3 \%$ & 14 & $46.7 \%$ & \multirow{2}{*}{$<0.005$} \\
\hline & $\begin{array}{l}\text { Elevation } \\
\text { grade } 2\end{array}$ & 26 & $86.7 \%$ & 16 & $53.3 \%$ & \\
\hline \multirow{2}{*}{1 week } & $\begin{array}{l}\text { No elevation } \\
\text { in Add }\end{array}$ & 26 & $86.7 \%$ & 22 & $73.3 \%$ & \multirow{2}{*}{$>0.05$} \\
\hline & $\begin{array}{l}\text { Elevation } \\
\text { grade } 1\end{array}$ & 4 & $13.3 \%$ & 8 & $26.7 \%$ & \\
\hline \multirow{2}{*}{1 month } & $\begin{array}{l}\text { No elevation } \\
\text { in Add }\end{array}$ & 26 & $86.7 \%$ & 20 & $66.7 \%$ & \multirow{2}{*}{$>0.05$} \\
\hline & $\begin{array}{c}\text { Elevation } \\
\text { grade } 1\end{array}$ & 4 & $13.3 \%$ & 10 & $33.3 \%$ & \\
\hline \multirow{2}{*}{3 months } & $\begin{array}{l}\text { No elevation } \\
\text { in Add }\end{array}$ & 26 & $86.7 \%$ & 20 & $66.7 \%$ & \multirow{2}{*}{$>0.05$} \\
\hline & $\begin{array}{l}\text { Elevation } \\
\text { grade } 1\end{array}$ & 4 & $13.3 \%$ & 10 & $33.3 \%$ & \\
\hline \multirow{2}{*}{6 months } & $\begin{array}{c}\text { No elevation } \\
\text { in Add }\end{array}$ & 26 & $86.7 \%$ & 20 & $66.7 \%$ & \multirow{2}{*}{$>0.05$} \\
\hline & $\begin{array}{c}\text { Elevation } \\
\text { grade } 1\end{array}$ & 4 & $13.3 \%$ & 10 & $33.3 \%$ & \\
\hline
\end{tabular}

$\mathrm{X} 2$ : Chi-square test.

There was no statistical significant difference between group A and group B as regard pattern evaluation at (pre- operative, 1 week, 1 month, 3 months and 6 months (Table 3). 
COMPARATIVE STUDY BETWEEN INFERIOR OBLIQUE RECESSION... 537

Table (3): Comparison between group A and group B as regard pattern evaluation

\begin{tabular}{|l|c|c|c|c|c|c|}
\hline \multirow{2}{*}{ Pattern } & Groups & \multicolumn{2}{c|}{$\begin{array}{c}\text { Group A } \\
(\mathbf{N = 3 0})\end{array}$} & \multicolumn{2}{c|}{$\begin{array}{c}\text { Group B } \\
(\mathbf{N = 3 0})\end{array}$} & \multirow{2}{*}{ P-value } \\
\hline Pre-operative & V pattern & 30 & $100 \%$ & 30 & $100 \%$ & ---- \\
\hline \multirow{2}{*}{$\mathbf{1}$ week } & Collapsed & 26 & $86.7 \%$ & 22 & $73.3 \%$ & \multirow{2}{*}{$\mathbf{0 . 0 5}$} \\
\cline { 2 - 7 } & Residual & 4 & $13.3 \%$ & 8 & $26.7 \%$ & \\
\hline \multirow{2}{*}{$\mathbf{1}$ month } & Collapsed & 26 & $86.7 \%$ & 22 & $73.3 \%$ & \multirow{2}{*}{$\mathbf{0 . 0 5}$} \\
\cline { 2 - 7 } & Residual & 4 & $13.3 \%$ & 8 & $26.7 \%$ & \\
\hline \multirow{2}{*}{ months } & Collapsed & 26 & $86.7 \%$ & 20 & $66.7 \%$ & \multirow{2}{*}{$\mathbf{0 . 0 5}$} \\
\cline { 2 - 6 } & Residual & 4 & $13.3 \%$ & 10 & $33.3 \%$ & \\
\hline \multirow{2}{*}{ 6 months } & Collapsed & 26 & $86.7 \%$ & 20 & $66.7 \%$ & \multirow{2}{*}{$\mathbf{0 . 0 5}$} \\
\cline { 2 - 6 } & Residual & 4 & $13.3 \%$ & 10 & $33.3 \%$ & \\
\hline
\end{tabular}

X2: Chi-square test.

Statistically significant difference occurred between group A and group B as regard pre-operative torsion evaluation. No statistical significant difference was

Table (4): Comparison between group $A$ and group $B$ as regard objective fundus torsion evaluation

\begin{tabular}{|c|c|c|c|c|c|c|}
\hline \multicolumn{2}{|c|}{ Torsion $\quad$ Groups } & \multicolumn{2}{|c|}{$\begin{array}{c}\text { Group A } \\
(\mathbf{N}=\mathbf{3 0})\end{array}$} & \multicolumn{2}{|c|}{$\begin{array}{c}\text { Group B } \\
(\mathbf{N}=\mathbf{3 0})\end{array}$} & \multirow[t]{2}{*}{ P-value } \\
\hline \multirow{3}{*}{$\begin{array}{l}\text { Pre- } \\
\text { operative }\end{array}$} & No torsion & 0 & $0.0 \%$ & 4 & $13.3 \%$ & \\
\hline & $\begin{array}{c}\text { Extorsion } \\
\text { grade } 1\end{array}$ & 8 & $26.7 \%$ & 12 & $40 \%$ & \multirow[t]{2}{*}{0.037} \\
\hline & $\begin{array}{l}\text { Extorsion } \\
\text { grade } 2\end{array}$ & 22 & $73.3 \%$ & 14 & $46.7 \%$ & \\
\hline \multirow[b]{2}{*}{1 week } & No torsion & 26 & $86.7 \%$ & 20 & $66.7 \%$ & \multirow[b]{2}{*}{$>0.05$} \\
\hline & $\begin{array}{c}\text { Extorsion } \\
\text { grade } 1\end{array}$ & 4 & $13.3 \%$ & 10 & $33.3 \%$ & \\
\hline \multirow[b]{2}{*}{1 month } & No torsion & 26 & $86.7 \%$ & 20 & $66.7 \%$ & \multirow[b]{2}{*}{$>0.05$} \\
\hline & $\begin{array}{c}\text { Extorsion } \\
\text { grade } 1\end{array}$ & 4 & $13.3 \%$ & 10 & $33.3 \%$ & \\
\hline \multirow[b]{2}{*}{3 months } & No torsion & 26 & $86.7 \%$ & 20 & $66.7 \%$ & \multirow[b]{2}{*}{$>0.05$} \\
\hline & $\begin{array}{c}\text { Extorsion } \\
\text { grade } 1\end{array}$ & 4 & $13.3 \%$ & 10 & $33.3 \%$ & \\
\hline \multirow[b]{2}{*}{6 months } & No torsion & 26 & $86.7 \%$ & 20 & $66.7 \%$ & \multirow[b]{2}{*}{$>0.05$} \\
\hline & $\begin{array}{c}\text { Extorsion } \\
\text { grade } 1\end{array}$ & 4 & $13.3 \%$ & 10 & $33.3 \%$ & \\
\hline
\end{tabular}

X2: Chi-square test.

\section{DISCUSSION}

Concerning the correction of elevation in adduction (IOOA grade) \& V pattern, In our study we found out that both IO graded recession and IO myopexy were equally effective in correcting the degree found between group A and group B as regard torsion evaluation at 1 week, 1 month, 3 months and 6 months (Table 4). 
corrected (residual grade 1) with constant result at first weak ,first month, 3 months and 6 months compared to IO myopexy with $73.3 \%$ full correction(no elevation in adduction), $26.7 \%$ under-correction (residual grade 1) at first weak and $66.7 \%$ full correction, $33.3 \%$ under-correction (residual grade 1) at first month,3 months and 6 months. And collapsed v pattern in graded IO recession by $86.7 \%$ and residual v pattern by $13.3 \%$ with constant result at first weak, first month, 3 months and 6 months compared to IO myopexy with collapsed $\mathrm{v}$ pattern by $73.3 \%$ and residual $v$ pattern by $26.7 \%$ at first weak and first monthand $66.7 \%$ collapsed $\mathrm{v}$ pattern $33.3 \%$ residual $\mathrm{v}$ pattern at 3 months and 6 months.

Bilateral graded recession of the inferior oblique for $\mathrm{V}$ pattern esotropia with IOOA was studied by Calderia, 2003, with results, in Group 1, 83\% had less than $15 \mathrm{PD}$ of $\mathrm{V}$ pattern or less than 10 PD of A pattern. Surgery reduced a pre-surgical vertical imbalance, but created a vertical deviation in some cases devoid of hypertropia before surgery. After surgery in Group 2, a full correction was obtained in $63.1 \%$ of the patients and an overcorrection to an A pattern in 21.0, a good outcome with collapse of $\mathrm{V}$ pattern was noted and the authors advised bilateral weakening of IO by graded recession for deviations less than $15 \Delta$ (Crisp et al., 2020).

A similar technique to IO Myopexy was described by Tomarchio et al., (2015) patients with inferior oblique muscle overaction were selected to undergo the surgical procedure. With results, Four months after surgery, the mean angle of deviation was reduced to $8 \mathrm{PD}$ exotropia in the group of 5 patients with $\mathrm{V}$-pattern esotropia; the patient with unilateral inferior oblique over action had the vertical deviation reduced to $3 \mathrm{PD}$. Finally, 2 patients with essential infant esotropia had a complete resolution of the elevation in adduction with no residual vertical imbalance. All patients experienced an improvement in lateral incomitance.

Concerning the correction of objective fundus extorsion, In our study we found out that both IO graded recession and IO myopexy were equally effective in correcting the degree of objective fundus extorsion (No statistical significant difference) whereas in graded IO recession; $86.7 \%$ of patients with no extorsion and $13.3 \%$ with residual extorsion grade 1 according to Guyton grading system with constant result at first weak ,first month, 3 months and 6 months compared to IO myopexy with $66.7 \%$ of patients with no extorsion and $33.3 \%$ with residual extorsion grade 1 with also constant result at first weak ,first month,3 months and 6 months.

Santiago et al., in their prospective study on the effect of anterior transposition of the inferior oblique on objective torsion with the use of fundus photography in 24 eyes of 13 patients. They concluded that Anterior transposition of the inferior oblique muscle initially decreased objective excyclotorsion, but the effect decayed beyond 10 weeks and the residual postoperative excyclotorsion was associated with a recurrence of inferior oblique overaction that mean that a lack of change of ocular torsion after a weakening procedure of the inferior oblique could 
serve as a predictor of recurrence of inferior oblique overaction (Gold, 2019).

\section{CONCLUSION}

Recession of inferior oblique muscle and retro equatorial scleral fixation (myopexy) of inferior oblique muscle surgical groups had positive outcomes, with good effect along the follow up visits up till 6 months and stable. We didn't propose a 'one-surgery-fits-all' approach to IOOA, as surgery on other vertical muscles may be indicated based on specific alignment measurements, as well as the presence or absence of head tilt or extortion.

\section{REFERENCES}

1. Chang, M. Y., Coleman, A. L., Tseng, V. L., and Demer, J. L. (2017): Surgical interventions for vertical strabismus in superior oblique palsy. Cochrane Database of Systematic Reviews (11-525-530).

2. Crisp, B. F., Olivella, S., \& Rosas, G. (2020): The Chain of Representation: Preferences, Institutions, and Policy across Presidential Systems: Cambridge University Press (162-166).
3. Gold, D. R. (2019): Eye Movement Disorders: Nystagmus and Nystagmoid Eye Movements. In Liu, Volpe, and Galetta's Neuro-Ophthalmology (pp. 585-610): Elsevier.

4. Rajavi Z, Feizi M, Behradfar N, Yaseri M, Sayanjali S, Motevaseli T, Sabbaghi $H$ and Faghihi M. (2017): Inferior Oblique Overaction: Anterior Transposition Versus Myectomy, J Pediatr Ophthalmol Strabismus.;54(4):232 -237.

5. Stager D. J, Lori M. D and Joost F. (2015): The inferior oblique muscle, Middle East African Journal of Ophthalmology, Volume 22(3), 122-130.

6. Tomarchio S, Sabetti L, Tomarchio $M$ and Berarducci A. (2015): New Surgical Intervention for the Weakening of the Inferior Oblique Muscle: Equatorial Scleral Anchor. J Pediatr Ophthalmol Strabismus.; 52(1):58-60.

7. Wright KW (2012): Inferior Oblique Muscle weakening procedures, 3rd ed: Color Atlas of strabismus surgery Springer science + Business Media, Inc(USA);; 166-179. 
در اسة مقارنة بين تقديم العضلة المائلة السفلية وبين تثبيتهاالخلفي بصلبة العين لمناجزة زيادة النشاط الأولي للعضلة المائلة السفلية

محمود محمد إسماعيل، محمد أحمد وهدان، هبه متولي علي، أحمد سمير عباس قسم طب و جراحة العين، كلية الطب، جامعة الأزهر

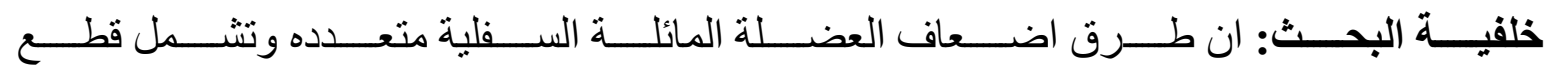

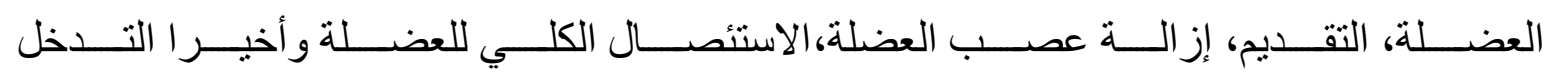
الجر احي الجديد لاضعاف هذه العضلة وهو التثبيت الخلفي للعضلة بصلبة العين.

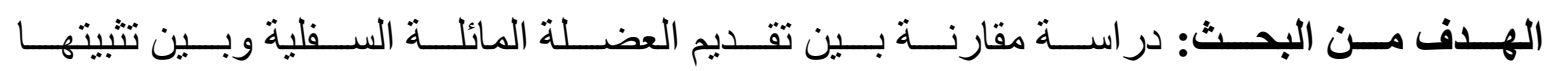
الخلفي بصلبة العين لمناجزة زيادة النشاط الأولي للعضلة المائلة السفلية.

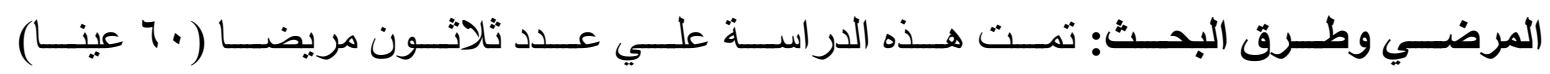

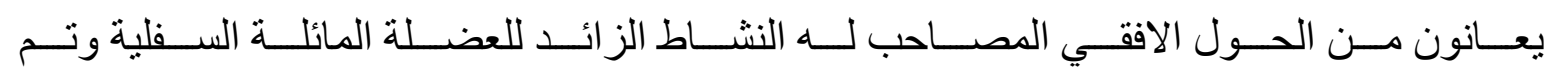

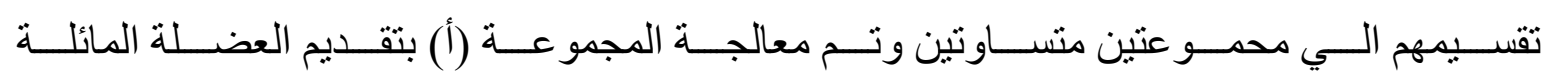
السفلية و المجموعة (ب) بالتثبيث الخلفي للعضلة بصلبة العين.

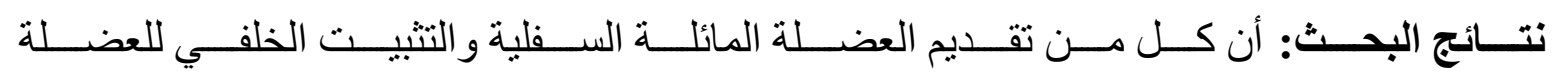

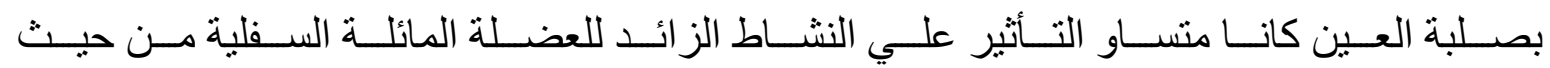

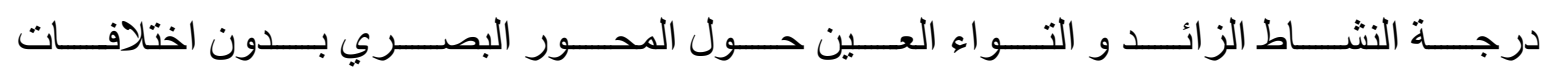
إحصائية ملموسه.



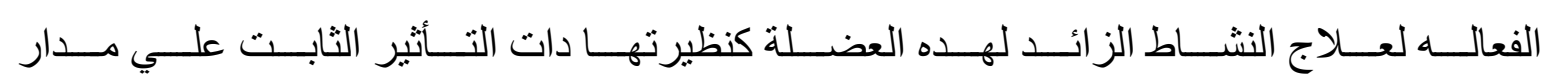
الثهور. 